\title{
Host Influence on the Ultrastructure of Root Nodules of Lupinus luteus and Ornithopus sativus
}

\author{
BY D. K. KIDBY \\ Department of Soil Science and Plant Nutrition, Institute of Agriculture, \\ The University of Western Australia, Nedlands, Western Australia \\ AND D. J. GOODCHILD \\ Division of Plant Industry, C.S.I.R.O., Canberra, A.C.T.
}

(Received 8 March 1966)

\section{SUMMARY}

The ultrastructure of Lupinus luteus L. and Ornithopus sativus Brot. root nodules derived from infection by Rhizobium lupini strain $\mathbf{D} 25$ was examined. In both cases the associations produced completely effective nodules but their gross morphology was markedly different. Bacteria within the $\boldsymbol{O}$. sativus nodules were enclosed in groups by a membranous envelope, and the bacteria had electron translucent regions. Bacteria within the $L$. luteus nodules were enclosed singly and did not exhibit similar electron translucent regions. Starch granules were observed within infected cells of $\boldsymbol{L}$. luteus but not within uninfected cells; the reverse was observed in $O$. sativus cells.

\section{INTRODUCTION}

Electron microscope investigations of structural relationships between the bacteria and host cell in legume root nodules were first undertaken by Bergersen \& Briggs (1958). Extensive studies in this field have subsequently appeared in the literature (Dart \& Mercer, 1963a-c, 1964; Mosse, 1964; Jordan, Grinyer \& Coulter, 1963; Dixon, 1964). A common feature of these investigations has been the demonstration of a membrane surrounding one or more bacteroids at the bacteroid stage of nodule development. The origin of this membrane, following the release of bacteria from the infection thread, appeared to differ in different legume species (Dixon, 1964; Jordan et al. 1963); this was not investigated in the work.

Starch deposits within infected host cells of Trifolium nodules have been noted by Dart \& Mercer (1964), but the identity of storage substrate within the bacteria of fully effective nodules has not generally been well defined. Mosse (1964) tentatively identified electron-translucent regions within bacteria in Trifolium nodules as carbohydrate; however carbohydrate inclusions are often associated with ineffectiveness (Bergersen, 1957; Nutman, 1959; Golebiowska \& Sypniewska, 1962). In an examination of laboratory-grown rhizobia Vincent, Humphrey \& North (1962) identified electron-translucent regions within the cells as granules of poly- $\beta$ hydroxybutyric acid. This polymer has also been detected in nodules of Mimosa and Pueraria species (Forsyth, Hayward \& Roberts, 1958); however, Golebiowska \& Sypniewska (1962) reported the absence of lipid substances in Rhizobium lupini within nodules of Lupinus species. 
The present study forms part of a research programme aimed at elucidating some of the host-bacteria relationships at the biochemical level. Strain D 25 of Rhizobium lupini offers a unique approach to this study since it forms effective symbiotic associations with Lupinus luteus and with Ornithopus sativus. Thus differences in nodule ultrastructure between the two species may be attributed to host influences. Properties such as viability and morphology, which would enable classification of these nodule bacteria as either the normal rod or bacteroidal type, have been insufficiently examined to yield a definite separation according to the criteria adopted by Jordan (1962). Previous estimates (Spicher, 1954) indicate that the normal rod types may predominate in nodules of $L$. luteus and $O$. sativus. For these reasons, the term bacteroid has not been used in the present study.

\section{METHODS}

Rhizobium lupini strain D 25, used for seed inoculation, was grown on a yeastmannitol agar medium. Surface-sterilized seeds were inoculated and glasshouse grown on a sand + vermiculite medium (Bergersen, 1958). Nodules were harvested at 40 days and material selected from the central regions of the smallest and largest nodules of Lupinus luteus and from two regions, distal and proximal to the root respectively, of single Ornithopus sativus nodules. In terms of nodule development these selections were not exactly analogous since the nodules of $L$. luteus, unlike those of $\boldsymbol{O}$. sativus, do not possess a well-localized meristematic region. However, the two selections from each plant may be regarded as approximately comparable in terms of the age of the tissues selected. Leg haemoglobin, indicating nitrogenfixing activity, was present in all samples.

The embedding agent used was: Epon 812 (Shell Chemical Co., Sydney, New South Wales), 15 g.; Epikote 826, 8 g.; Epikote 871 (Indalab Pty. Ltd., Granville, New South Wales) 2.5 g.; CIBA Hardener HY 964, 21.5 g.; CIBA Hardener HY 906 (CIBA Co. Pty. Ltd., Lane Cove, New South Wales), 6.25 g.. To 35 g. of this, $0 \cdot 66$ g. of the catalyst DMP-30 (CIBA Accelerator Dy 064, CIBA Co. Pty. Ltd., Lane Cove, New South Wales) was added for polymerization.

Samples were fixed in $2.5 \%(\mathrm{v} / \mathrm{v})$ glutaraldehyde in $\mathbf{0} \cdot \mathbf{1} \mathrm{M}$ - phosphate buffer $\left(\mathrm{pH} 7 \cdot 0\right.$ ) for $12 \mathrm{hr}$ at $4^{\circ}$, washed in buffer alone with four changes over $2 \mathrm{hr}$ and then fixed with $\mathbf{2 . 0} \%(\mathrm{w} / \mathrm{v})$ osmium tetroxide in $\mathbf{0 . 1} \mathrm{M}$-phosphate buffer at $4^{\circ}$ for $2 \mathrm{hr}$ and washed as for pre-fixation. Dehydration was done in 25, 50, 70 and $100 \%$ $(\mathrm{v} / \mathrm{v})$ acetone in water in $\mathbf{3 0} \mathrm{min}$. steps, except for an overnight period in $\mathbf{7 0} \%$ acetone. The embedding polymer catalyst (DMP-30) was introduced in a $0.5 \%$ $(\mathrm{w} / \mathrm{w})$ solution in acetone for $30 \mathrm{~min}$. and followed by $2 \times 15 \mathrm{~min}$. washings with acetone. A $50 \%$ (w/w) solution of the embedding monomer (Epon) was introduced for $2 \mathrm{hr}$ and followed by a $24 \mathrm{hr}$ incubation at $45^{\circ}$ in Epon alone. Tissue samples were then placed in gelatin capsules, Epon (0.6\%, w/w, DMP-30) was added and polymerization allowed to proceed for 3 days at $60^{\circ}$.

An LKB Ultratome with glass knives was used for sectioning. Sections were stained with saturated uranyl acetate in $50 \%(\mathrm{v} / \mathrm{v})$ ethanol in water followed by a lead hydroxide stain (Karnovsky, 1961). 


\section{RESULTS}

\section{Gross morphology and development}

The different nodule habits of these plants are illustrated in $\mathrm{Pl}$. 1, figs. 1, 2. The 'single' nodule encircling the root of Lupinus luteus resulted from several separate sites of infection which had developed as discrete nodules and then merged together (material for electron microscopy was sampled just before this merging of separate infection sites). When sectioned, the apparently single nodule revealed discrete regions of infected tissue corresponding to the initial infection sites. Merging together of nodules was not exhibited by Ornithopus sativus, this was apparently due to the relatively localized meristematic region at the nodule tip. Unlike $L$. luteus nodules, which in healthy plants do not exhibit senescence until near the flowering stage, $O$. sativus nodules exhibit partial senescence, as evidenced by loss of leg haemoglobin, in the older region of the nodule at about 30 to 45 days after nodulation. This region occupies an increasingly larger proportion of the nodule until, at flowering, nearly all of the first formed nodules are devoid of leghaemoglobin.

\section{Electron microscopy}

The relationship of the bacteria to the enclosing membrane in the younger tissue in each host is illustrated in Pl. 2, figs. 3, 4. Membranes enclosed only one bacterium in Lupinus luteus while enclosed groups were common in Ornithopus sativus. In the older tissues ( $\mathrm{Pl}$. 3, figs. 5, 6), the region enclosed by each membrane was expanded and in $O$. sativus most membranes contained groups of bacteria, while in L. luteus only single bactera were enclosed. The latter observation is supported by the recent work of Jordan \& Grinyer (1965).

The presence of large electron-translucent regions in Ornithopus sativus nodule bacteria and their absence from Lupinus luteus is illustrated in Pl. 4, figs. 7, 8. The presence of starch grains within infected cells of $L$. luteus and in uninfected cells adjacent to infected cells in $O$. sativus is also illustrated in Pl. 4, figs. 7, 8. Mitochondria within infected host cells were similarly distributed in each species, being largely confined to the cell-wall regions, and in particular, adjacent to intercellular spaces. The numbers of mitochondria in infected cells appeared to be much greater than in uninfected cells.

\section{DISCUSSION}

The differences observed here in nodule ultrastructure suggest host control of (i) division of the membrane envelopes; (ii) certain bacterial cell inclusions; (iii) the site of deposition of starch within infected tissue. The enclosure of a group of bacteria by a single membrane envelope in Ornithopus sativus resembles the situation in soybean (Bergersen \& Briggs, 1958). The reason for this is unknown, but it is apparent that bacterial division, at least in the final one, two or three divisions, was not accompanied by division of the enclosing membrane which nervertheless continued to grow in size. Observations of ultrastructure in $O$. sativus nodules 50-60 days old showed that membrane expansion continued until very little of the host cell volume was external to the membrane envelopes. Thus the region enclosed by the membranes, external to the bacteria, became a very large proportion of the total volume of the plant cell. From the point of view of spatial relationships, this region 
suggests itself as a site of some importance in the metabolic interactions of bacteria and host.

The electron-translucent inclusions in Ornithopus sativus nodule bacteria closely resemble those observed in soybean which have been identified as granules of poly$\beta$-hydroxybutyric acid (Dr F. J. Bergersen, personal communications). However, chemical analysis indicates the absence of poly- $\beta$-hydroxybutyric acid from bacteria of either host species, although a large proportion of chloroform-extractable material, as yet unidentified, has been found. A sharp peak at 284 $\mathrm{m} \mu$ was obtained for this substance by the poly- $\beta$-hydroxybutyric acid assay method of Law \& Slepecky (1961). The host influence responsible for this difference in cellular inclusions is possibly one involving the nutritional environment but at present no essential biochemical differences have been found. The differences in the distribution of starch are not readily explicable and must await further biochemical elucidation. Both types of starch distribution have been described from light microscope studies of root nodules (Fred, Baldwin \& McCoy, 1932). The distribution of mitochondria suggests localization of certain metabolic processes and the reason for this localization might be explained in terms of an oxygen requirement not provided by the essentially anaerobic interior of an infected plant cell. Host influences on the nodule, including nodule size, absence or short-lived leg haemoglobin, glycogen inclusions within the bacteria, failure to develop the characteristic bacteriodal morphology and premature nodule senescence are well known in ineffective associations (Nutman, 1959). It is also evident that even in completely effective symbioses, the host plant may not only cause marked differences in the gross morphology of the nodule but also in ultrastructure within the infected cells, including the bacterial cell.

The authors thank Miss Margaret A. Paulin for her excellent technical assistance. One of us (D.K.K.) is indebted to Dr F. J. Bergersen who, in addition to much material assistance, arranged the use of facilities at the Division of Plant Industry, C.S.I.R.O., Canberra, where the electron microscopy was done. The investigation was made during tenure of an Australian Dairy Produce Board Senior PostGraduate Studentship. Acknowledgement is also due to the Board for additional financial assistance during the course of this investigation.

\section{REFERENCES}

Bergersen, F. J. (1957). The structure of ineffective root nodules of legumes: an unusual new type of ineffectiveness, and an appraisal of present knowledge. Aust. J. Biol. Sci. 10, 233.

Bergersen, F. J. (1958). The bacterial component of soybean root nodules; changes in respiratory activity, cell dry weight and nucleic acid content with increasing nodule age. J. gen. Microbiol. 19, 312.

Bergersen, F. J. \& Briggs, M. J. (1958). Studies on the bacterial component of soybean root nodules: cytology and organization in the host tissue. J. gen. Microbiol. 19, 482.

Dart, P. J. \& Mercer, F. V. (1963a). Membrane envelopes of legume bacteroids. J. Bact. $85,951$.

DarT, P. J. \& Mercer, F. V. (1963b). Development of the bacteroid in the root nodule of barrel medic (Medicago tribuloides Desr.) and subterranean clover (Trifolium subterraneum L.) Arch. Mikrobiol. 46, 382. 
Dart, P. J. \& Mercer, F. V. (1963c). The intracytoplasmic membrane system of the bacteroids of subterranean clover nodule (Trifolium subterraneum L.). Arch. Mikrobiol. 47, 1.

Dart, P. J. \& Mercer, F. V. (1964). Fine structure changes in the development of the nodules of Trifolium subterraneum L. and Medicago tribuloides Desr. Arch. Mikrobiol. 49, 209.

Drxon, R. O. D. (1964). The structure of infection threads, bacteria and bacteroids in pea and clover root nodules. Arch. Mikrobiol. 48, 166.

Forsyth, W. G. C., Hayward, A. C. \& Roberts, J. B. (1958). Occurrence of poly- $\beta$ hydroxybutyric acid in aerobic Gram-negative bacteria. Nature, Lond. 182, 800.

Fred, E. B., Baldwin, I. L. \& McCoy, E. (1932). Root nodule bacteria and leguminous plants. University of Wisconsin Studies. Madison.

Golebiowska, J. \& SyPNIEwska, U.(1962). Studies on the development cycle of Rhizobium lupini in root nodules. Acta microbiol. polon. 11, 313.

Jondan, D. C. (1962). The bacteroids of the genus Rhizobium. Bact. Rev. $26,119$.

Jordan, D. C. \& Grinyer, I. (1965). Electron microscopy of the bacteroids and root nodules of Lupinus luteus. Can. J. Microbiol. 11, 721.

Jordan, D. C., Grinyer, I. \& Coulter, W. J. (1963). Electron microscopy of infection threads and bacteria in young root nodules of Medicago sativa. J. Bact. 86, 125.

KARnovksy, M. J. (1961). Simple methods for 'staining with lead' at high pH in electron microscopy. J. biophys. biochem. Cytol. 11, 729.

LAw, J. H. \& Slepecky, R. A. (1961). Assay of poly- $\beta$-hydroxybutyric acid. J. Bact. 82, 33.

Mosse, B. (1964). Electron-microscope studies of nodule development in some clover species. J. gen. Microbiol. 36, 49.

Nutman, P.S. (1959). Sources of incompatibility affecting nitrogen fixation in legume symbiosis. Sym. Soc. exp. Biol. 13, 42.

SpIChER, G. (1954). Lebensdauer und Stickstoffbindung der Knöllchenbakterien von Lupine, Serradella und Klee in Abhängigkeit von ihrer Gestalt. Zentbl. Bakt. Parasit.-Kde (Abt 2), 107, 383.

Vincent, J. M., Humphrey, B. \& North, R. J. (1962). Some features of the fine structure and chemical composition of Rhizobium trifolii. J. gen. Microbiol. 29, 551.

\section{EXPLANATION OF PLATES}

Key to symbols. $B$, bacterium; $S t$, starch; $M$, mitochondrion; $E t$, electron translucent areas in bacteria; $C$ w, cell wall of host cell; $E m$, enclosing membrane.

Electron micrographs are from tissue of nitrogen-fixing nodules fixed in $2.5 \%(\mathrm{v} / \mathrm{v})$ glutaraldehyde followed by $2 \%(\mathrm{w} / \mathrm{v})$ osmium tetroxide. The tissue pieces were embedded in Epon and sections were stained with uranyl acetate and lead hydroxide.

\section{Plate 1}

Fig. 1. Lupinus luteus plant with nodule encircling the root.

Fig. 2. Ornithopus sativus plant with many nodules developed on the root system.

Plate 2

Fig. 3. Young Lupinus luteus nodule tissue showing bacteria enclosed singly by a membrane.

Fig. 4. Young Ornithopus sativus nodule tissue showing one or more bacteria enclosed by a single membrane.

Plate 3

Fig. 5. Old Lupinus luteus nodule tissue showing bacteria enclosed singly by a membrane with an enlarged electron transparent region between the membrane and the bacterium.

Fig. 6. Old Ornithopus sativus nodule tissue showing up to six bacteria enclosed by a single membrane and an enlarged electron transparent region between electron translucent areas within the bacteria. 


\section{Plate 4}

Fig. 7. Lupinus luteus nodule tissue showing the presence of starch grains within cells infected with bacteria.

Fig. 8. Ornithopus sativus nodule tissue showing the presence of starch grains in a cell adjacent to an infected cell, and electron translucent areas within the bacteria. 

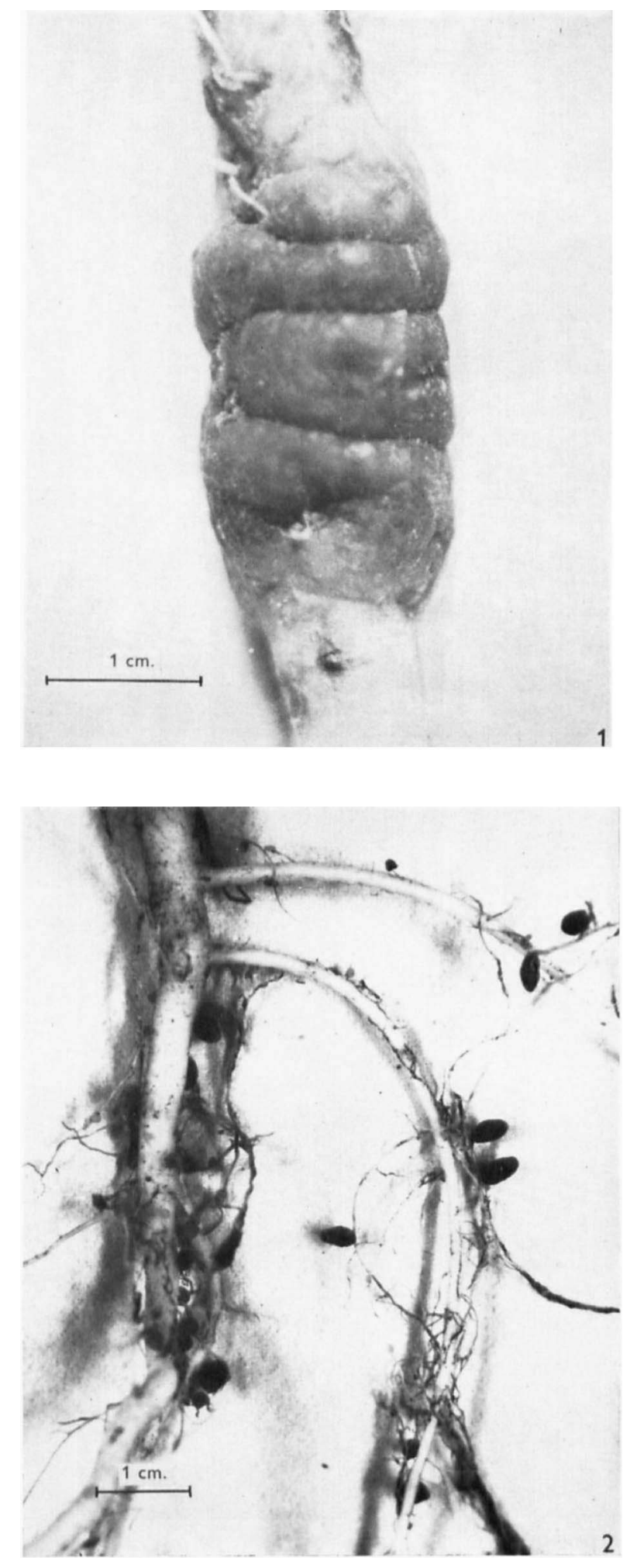

D. K. KIDBY AND D. J. GOODCHILD 

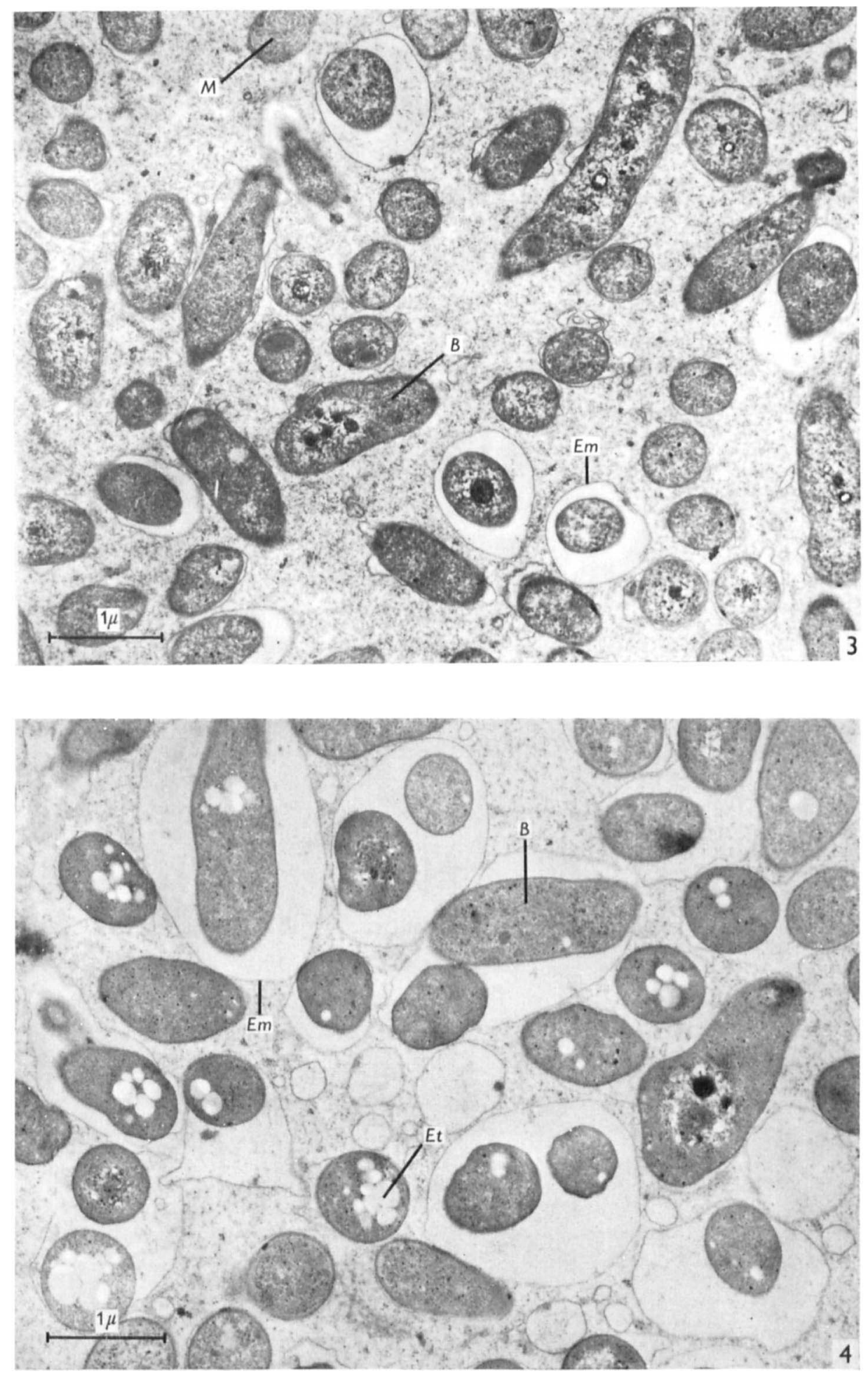

D. K. KIDBY AND D. J. GOODCHILD 

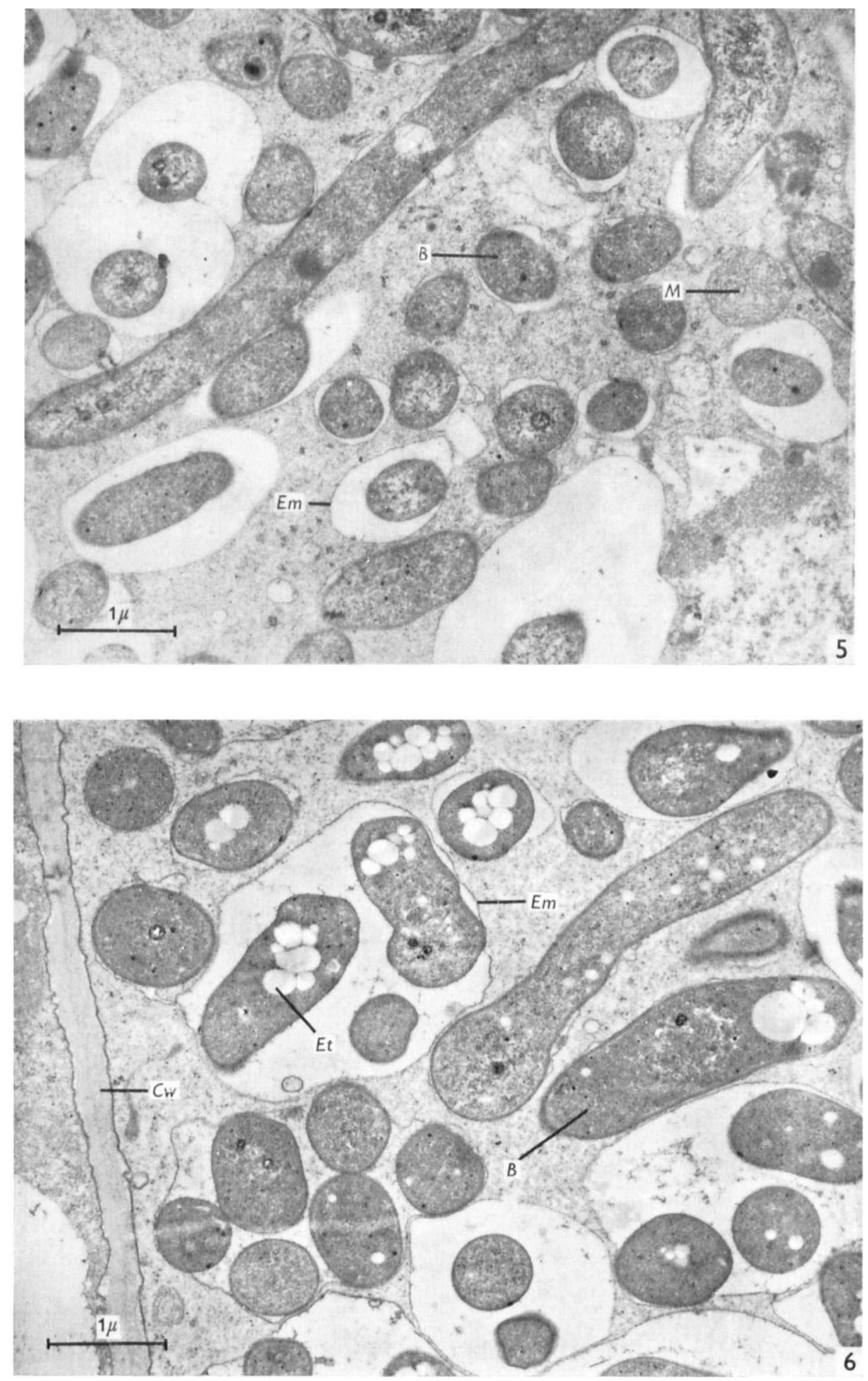

D. K. KIDBY AND D. J. GOODCHILD 

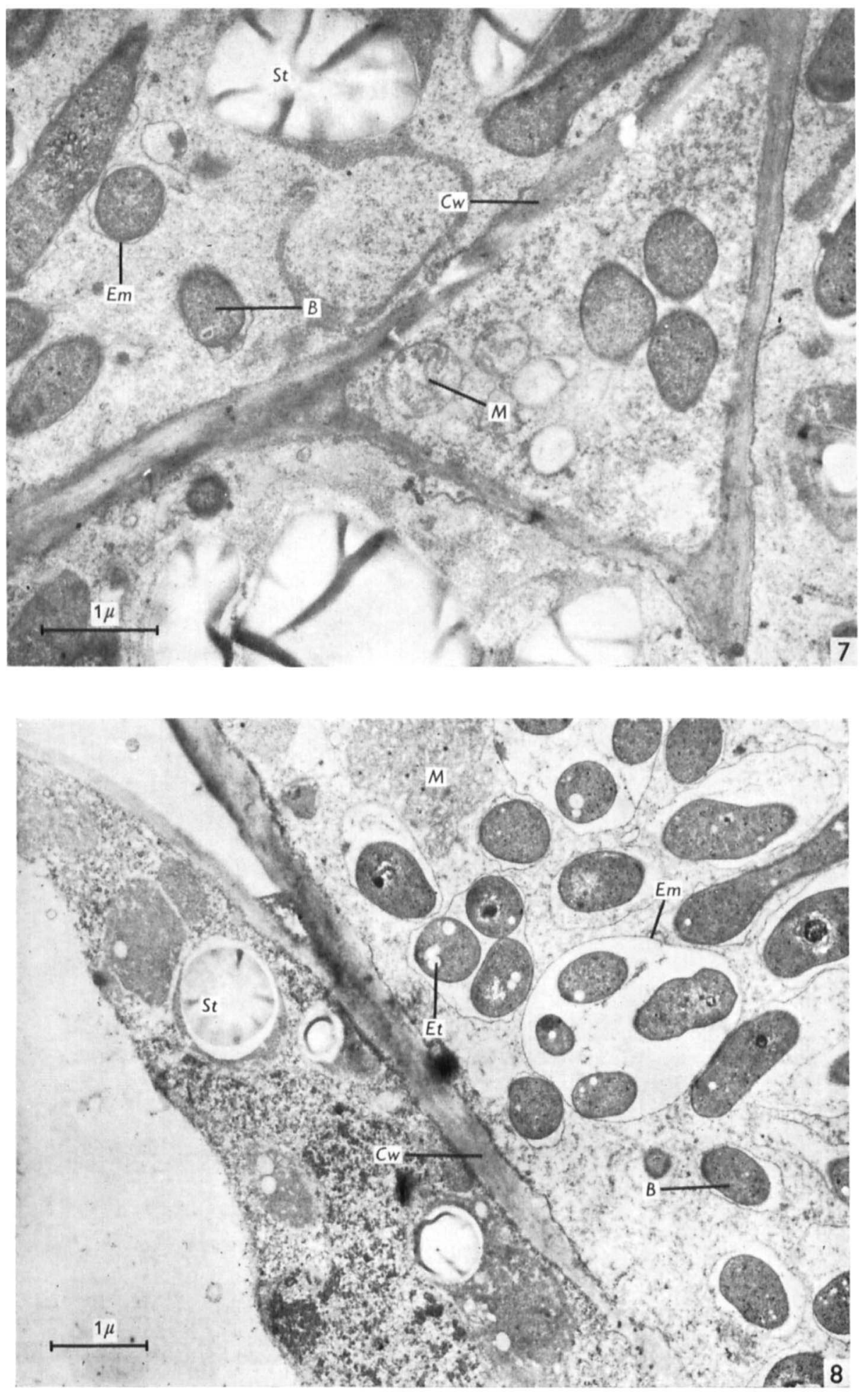

D. K. KIDBY AND D. J. GOODCHILD 